\title{
The Effectiveness of Sea-Based Blended Learning eBook on The Subject of Cookies and Candies
}

\author{
Anggri Sekar Sari ${ }^{1}$, Siti Mariah ${ }^{2}$ \\ anggri.sekar@gmail.com¹, siti.mariah@ustjogja.ac.id ${ }^{2}$ \\ Universitas Sarjanawiyata Tamansiswa, Yogyakarta, Indonesia ${ }^{12}$
}

\begin{abstract}
Utilization of smartphones that have not been maximized in education is inversely proportional to lifestyle. Therefore, the need for a learning media that can be applied to the smartphone. As a distance learning solution through digital sea learning. This study aims to determine the effectiveness of learning using eBook. The research method used quasi-experiment with pre-test and post-test design. Research subjects are 70 students of Home Economic Education who follow cookies and candies. Validity test using biserial point formula with the result of 26 valid test items. Reliability test using Kuder-Richardson 20 formula where reliability value is reliable. The prerequisite analysis test includes a normality test in which the data is normally distributed. While homogeneity test of variance obtained data is homogeneous. Hypothesis test using t-test shows that $\mathrm{t}_{\mathrm{he}}=8.884>\mathrm{t}_{\mathrm{t}} 68, \alpha 5 \%=1,990$. The result of the research is there is the effectiveness of learning using sea-based digital learning eBook.
\end{abstract}

Keywords: effectiveness, sea-based learning, eBook

\section{Introduction}

Teaching and learning process is a communication process between lecturers and students [1] [2]. Some obstacles often occur in the communication process. One of the challenges in communication between lecturers and students is less precisely media as a communication tool. Learning media used less effective due to media that is old and not in accordance with the development of the era. Though one of the functions of the media as a stimulus to students.

One of the factors to meet the learning achievement required the appropriate media [3]. The use of proper and interactive media in learning can stimulate learning in learners also reduce the passive attitude of learners [4]. The purpose of media often used in education includes two-dimensional media that provides for projection media and print media and three-dimensional media. Learning media is considered less stimulating students because it is not flexible and can not be used at any time. The media is less desirable by students because it takes more time to find and read it. In order for students to be stimulated to learn, the need for a learning media that is packaged more interesting in accordance with the times. Press as one of the tools in learning can use interactive media to stimulate students to love learning. Interactive learning media can use the smartphone as one of the messaging apparatus to students. Where the use of such media can create an attraction for students.

The development of smartphones as one of mobile technology at this time so rapidly. Moreover, balanced with various features that facilitate the wearer to communicate and social networking with the internet in it. This is evidenced by 143.26 million people using the internet of 262 million total internet users, of which 44, 16\% use smartphones to access the internet [5]. In conclusion, more than $60 \%$ of Indonesians own a smartphone as a means of communication and social networking.

One of the mobile devices that are now commonly used is mobile phones. Nearly $90 \%$ of students already have a cell phone or even have more than one cell phone. Smartphones are one of many technological developments that can be called high-class technology due to its superiority. The growth of smartphones is quite rapidly motivated by the needs of people who want to work quickly and solving problems too fast without the need to meet in person. Smartphones today are very helpful in a variety of human needs, one of which helps users to work and communicate directly. Therefore the mention of smartphones as a smartphone is the reason for the development of variations of smartphones to date even quite popular in the field of education[6].

The use of smartphones in Indonesia is not only used in learning alone but used in various activities. According to data from the Association of Internet Service Providers Indonesia utilization of the internet field of 
education is less than the use of the internet for the area of lifestyle. Internet utilization according to Association of Internet Service Providers Indonesia, education field as much as $21.73 \%$ is used as an educational article while $87.73 \%$ is used as a social media [5]. N Wulandari, argues that $65.98 \%$ of students use smartphones for lifestyle in the form of social media [7]. The use of smartphones from among students of $90 \%$ with a note that the use of smartphones more widely used for personal purposes than to help the learning process [8][9]. The method of smartphones for own goals and aims as a lifestyle. The application includes covering social networks and some content that is not worth following such as networks that emphasize the elements of racial intolerance, discrimination, and even pornography. Rather than the continued use of smartphones and can damage the nation's generation there is a need to use the smartphone as one of the smartphones to help improve learning.

The increase can be done by providing educative content and as a source of learning through eBooks according to the times. The application of instructional media with eBooks serves to reduce the adverse effects of social media, also a solution for students in learning and distance learning. In addition, sea-based learning eBook is one learning that is quite interactive. This learning uses one of the learning method of virtual education, where lecturers and students do not need to meet in one room to carry out training. Differences in learning through sea digital learning using eBooks can make students more independent and reactive than conventional knowledge. Learning using eBooks in this research is further research that is developing digital pocketbooks cookies and candies and continued to test the effectiveness of eBooks on learning cookies and candies. Some of the problems that have been described can be formulated that whether the ebook based on sea digital learning effectively used in teaching cookies and candies.

The purpose of research to determine the effectiveness of sea-based learning eBook on the subject of cookies and candies. The subject matter taken in this course is the knowledge and processing of candy. The results of this study are one of the supporting learning media that is expected to improve the quality of learning cookies and candies in accordance with the competence of Culinary expertise. eBooks developed through the application of Sigil function to enhance student understanding, stimulate and easy to use by students. In addition, sea-based learning eBook can be used without limited space and time and can be used by the general public.

Benefits of research are expected to add insight and reference for the implementation of learning by using media, especially learning media practice culinary. Providing an alternative to culinary practice learning so that it can access learning materials whenever and wherever, can provide insight and add insight to alternative learning media that are interesting and useful for learning activities. Reduce student addiction in the use of smartphones by utilizing it in learning. In addition, it can be used for distance learning.

\section{Research Methodology}

This research uses quasi-experiment with pre-test and post-test control group design. The selection of pretest and post-test designs through the control group is not randomized. The results of a good pre-test when the experimental group value did not differ significantly and post-test results there are significant differences that can be known from the influence of treatment that is $\left(\mathrm{O}_{2}-\mathrm{O}_{1}\right)-\left(\mathrm{O}_{4}-\mathrm{O}_{3}\right)$. The use of the research design can be seen in table one.

Table 1. Pre-test And Post-test Control Group Design

\begin{tabular}{llll}
\hline Group & Pre-test & Treatment & Post-test \\
\hline Experiment & $\mathrm{O}_{1}$ & $\mathrm{X}$ & $\mathrm{O}_{2}$ \\
Control & $\mathrm{O}_{3}$ & - & $\mathrm{O}_{4}$ \\
\hline
\end{tabular}

Information:

$\mathrm{O}_{1}=$ Initial test (preliminary learning result) in the experimental class.

$\mathrm{O}_{2}=$ Final test (final learning result) in the experimental class

$\mathrm{O}_{3}=$ Initial test (preliminary learning result) in the control class

$\mathrm{O}_{4}=$ Final test (final learning result) in the control class

$\mathrm{X}=$ Treatment with the use of digital books in the experimental class

- = No treatment in the control class 
Data collection on quasi-experiment research using documentation and test. Analysis of data used is quantitative or statistical aims to test the hypothesis that has been set. Researchers took the place of research in Home Economic Education Department, Faculty of Teacher Training and Education, Universitas Sarjanawiyata Tamansiswa Yogyakarta. The sample used in this study is all students of Home Economic Education Department Culinary concentration amounting to 70 people (total sampling).

The trial in this study was conducted on 30 students outside the study respondents. After the test, validity in the analysis using Product Moment formula from Karl Pearson with an assisted statical package for the social sciences (SPSS) program version 20. Test validity is calculated using Product Moment formula from Karl Pearson. Further, the price is consulted with $r$ table with significant level $5 \%$ with $r$ table is said valid if price $r_{x y}$ $\geq r_{\text {table }}$ ( $r$ count is bigger or equal to $r$ table), and vice versa. The result of validity test on 35 test items, it was found that 26 test items were valid while 9 test items were declared void. The test instruments used in the study were 26 items with the problem number: $1,2,4,5,6,8,9,11,13,14,15,16,17,18,20,22,23,24,25,27$, $28,30,31,32,33,34$. The reliability test in this research uses KR-20 formula, the use of this formula because instrument score is score 1 and 0 . The test results revealed the magnitude of the instrument reliability coefficient is 0.884 which means reliable. Where the value is in the high category.

The prerequisite analysis test uses the data normality test where the test can use Kolmogorov-Smirnov test with the decision criteria is if the calculation result of significantly more significant than $5 \%$ significance value $(0,05)$ then the data stated normal distribution. The homogeneity test of variance is a C-test (Cochran test), by comparing the most considerable difference with the smallest deviation. Calculation results are then consulted with the table; in this calculation, Ho accepted when $\mathrm{C}_{\text {ount }}<\mathrm{C}_{\text {table }}$ and degree significance of $5 \%$ and $\mathrm{DB}=\mathrm{N}-1$.

The analytical techniques used t-test between groups. Inter-group t-tests were used to test the significance level of the mean differences between the two groups. Where t-test between groups is used to examine the differences in the effectiveness of learning without digital books with learning using digital textbooks. Criteria for decision making is if $\mathrm{p}<0.05$ then the hypothesis is accepted, otherwise, if $\mathrm{p}>0.05$, then the theory is rejected.

Before the experiment is done first examined the subject of research, which consists of students in the experimental class and control class. Further examination conducted on experimental and non-experimental variables that are assumed will affect the subjective of research results are:

1. The early ability of students with a pre-test. The student's old ability was used to estimate the effect of the matching bias between the control class and the experimental class. The given pre-test includes the overall material to be administered during the treatment of the calculation results obtained $t_{0}<t_{t}$ there is no difference between the control class at the experimental level. The results show no subjective between the two groups.

Table 2. T-test Results Independent Data Pre-test Experiment Group and Control Group

\begin{tabular}{llllll}
\hline Data & $\mathrm{t}_{\mathrm{c}}$ & $\mathrm{t}_{\mathrm{t}}$ & $\mathrm{db}$ & $\mathrm{p}$ & information \\
\hline $\begin{array}{l}\text { Pre-test of } \\
\text { experimental }\end{array}$ & 0,110 & 1,996 & 68 & 0,909 & $\begin{array}{l}\mathrm{t}_{\mathrm{c}}<\mathrm{t}_{\mathrm{t}}=\text { there is no } \\
\text { difference }\end{array}$ \\
$\begin{array}{l}\text { group and control } \\
\text { group }\end{array}$ & & & & \\
\hline
\end{tabular}

2. The number of students in the class (the number of students in the experimental class and the control class of 35 students each) is equal and equal.

3. The classroom (seen from the school used during the learning process, between the experimental class and the control class is appropriate because the school used has the same conditions)

4. Teachers significantly affect the knowledge of students, so it needs to be paired first. Lecturers in the experimental class and control classes are made equal and considered to be balanced.

The experimental preparatory stage serves to prepare equipment, planning, and everything related to experiments technically such as preparation to make Semester Learning Design, space preparation, lesson time required, and media used. This stage is a treatment by using eBooks in the experimental class and printed books in the control class. Administration of this treatment is adjusted to the weight of semester four material. Each procedure takes 100 minutes (two hours of lessons), this lesson is changed to the lesson time in class A and B Cookies and Candie's courses. 
In the implementation of control class treatment and experimental class conducted by lecturer and researcher. The procedure was administered six times, with details of three meetings for the control class and three receptions for the trial category. Each one-hour treatment takes 100 minutes, while for the use of day and time of the surgery the researchers adjust to the schedule of Cookies and Candy's courses.

Implementation of class experimental treatment using eBook that is; the first step taken by the researcher is to open the meeting; then the lecturer explains the material to be given and studied at the meeting. After that student are given apperception about the presented document. The next step, lecturers provide materials to students using eBooks.

Furthermore, the lecturer asks students to study and look for material that has been submitted by using eBook. In this learning, students can not only learn in the classroom, but students can learn through eBook with the giving of the task by a lecturer. After the treatment is completed, then post-test is given at the end of treatment that serves to measure the effectiveness of the experimental class.

Implementation of classroom control less without using a printed book; first the lecturer opens the lesson, explains the material to be given and learned at the meeting. After that student are given apperception about the presented document. The next step, the lecturer told the article through the handbook owned by the students. After that, the lecturer gives the task to the students to deepen the stuff that has been given. After treatment is completed, then post-test is provided at the end of treatment to measure the effectiveness of the control class.

This stage the measurement stage of the treatment that has been given by giving test result of study and final observation. This last result is used to determine the difference caused by the treatment. Furthermore, the final outcome data of each class is processed and analyzed by using statistical analysis. Based on these results can be found which gives effectiveness on learning Cookies and Candies.

\section{Results and Discussion}

Data on the distribution normality test found that the pre-test and post-test of the experimental class and control class were declared healthy. It can be known if a Chi-Square value obtained from calculation result $\left(\mathrm{x}^{2}{ }_{c}\right)$ is smaller than a Chi-Square value obtained from the table $\left(\mathrm{x}_{\mathrm{t}}^{2}\right)$ at $5 \%$ significance level. Calculation values can be seen in table three.

Table 3. Normality Test

\begin{tabular}{|c|c|c|c|c|c|c|}
\hline$\overline{\text { Data }}$ & & $\overline{X_{c}^{2}}$ & $\overline{X_{t}^{2}}$ & $\overline{\mathrm{DB}}$ & $\bar{p}$ & information \\
\hline $\begin{array}{l}\text { Pre-test } \\
\text { experimental } \\
\text { group }\end{array}$ & of & 4,878 & 16,919 & 9 & 0,845 & $\mathrm{X}_{\mathrm{c}}^{2}<\mathrm{x}_{\mathrm{t}}^{2}=$ normal \\
\hline $\begin{array}{l}\text { Pre-test } \\
\text { kontrol group }\end{array}$ & of & 6,389 & 16,919 & 9 & 0,700 & $\mathrm{X}_{\mathrm{c}}^{2}<\mathrm{X}_{\mathrm{t}}^{2}=$ normal \\
\hline $\begin{array}{l}\text { Post-test } \\
\text { experimental } \\
\text { group }\end{array}$ & of & 13,550 & 16,919 & 9 & 0,139 & $\mathrm{X}^{2}{ }_{\mathrm{c}}<\mathrm{X}_{\mathrm{t}}^{2}=$ normal \\
\hline $\begin{array}{l}\text { Post-test } \\
\text { experimental } \\
\text { group }\end{array}$ & of & 15,532 & 16,919 & 9 & 0,077 & $\mathrm{X}_{\mathrm{c}}^{2}<\mathrm{X}_{\mathrm{t}}^{2}=$ normal \\
\hline
\end{tabular}

After testing the normality of data distribution then tested the homogeneity of the variant with C-test. The acquisition of pre-test and post-test data shows that the data is homogeneous. It can be known from the value of $\mathrm{C}$ arithmetic $\left(\mathrm{C}_{\mathrm{c}}\right)$ is smaller than $\mathrm{C}$ table $\left(\mathrm{C}_{\mathrm{t}}\right)$ at $5 \%$ significance level. Acquisition of data can be seen in table four.

Table 4. Homogeneity Test

\begin{tabular}{lllllll}
\hline Data & $\mathrm{C}_{\mathrm{c}}$ & $\mathrm{C}_{\mathrm{t}}$ & $\mathrm{DB}$ & $\mathrm{p}$ & information \\
\hline Pre-test & 1,017 & 88,241 & $1: 68$ & 0,465 & $\mathrm{C}_{\mathrm{c}}<\mathrm{C}_{\mathrm{t}}$ \\
homogeneous & $=$ \\
Post-test & 1,427 & 88,241 & $1: 68$ & 0,107 & $\begin{array}{l}\mathrm{C}_{\mathrm{c}}<\mathrm{C}_{\mathrm{t}} \\
\text { homogeneous }\end{array}$ \\
\hline
\end{tabular}


Data analysis aims to test the research hypothesis, namely to determine the difference in the effectiveness of learning using printed books (control) with learning using eBook (experimental). Here is the data analysis using the t-test can be seen in table five.

Table 5. t-Test

\begin{tabular}{|c|c|c|c|c|c|}
\hline Data & $t_{c}$ & $t_{t}$ & DB & $\mathrm{p}$ & information \\
\hline $\begin{array}{l}\text { Pre-test and post- } \\
\text { test of control } \\
\text { group design }\end{array}$ & 0,177 & 1,996 & 68 & 0,854 & $\begin{array}{l}\mathrm{t}_{\mathrm{c}}<\mathrm{t}_{\mathrm{t}} \quad=\quad \text { no } \\
\text { difference }\end{array}$ \\
\hline $\begin{array}{l}\text { Pre-test and Post- } \\
\text { test of } \\
\text { experimental } \\
\text { group design }\end{array}$ & 8,884 & 1,996 & 68 & 0,000 & $\begin{array}{l}\mathrm{t}_{\mathrm{c}}<\mathrm{t}_{\mathrm{t}}=\text { There is a } \\
\text { difference }\end{array}$ \\
\hline
\end{tabular}

Table five explains that the value of $t$ arithmetic is higher than the amount of $t$ table $\left(t_{c}>t_{t}\right.$ or $8,884>$ 1,996). Hypothesis testing can be known from Ho is rejected, while Ha accepted. Meaning: based on the calculation of student test results, there are significant differences in experiment class before and after learning using eBook. The effect of the pre-test of the students 'knowledge of the experimental class and the control class shows that there is no difference in the level of students' learning knowledge between the two classes can be indicated by the value of $t$ count smaller than the amount of $t$ table $(0,110<1,996)$. It proves that the experimental class and control class depart from the same starting point (no subjective).

There are several factors that cause student knowledge in the initial conditions are still low. Among them, the lack of controlled classes at the time of both experiment and control class learning because the classroom practice is used for theory. Students only use printed books in education. Frequent knowledge independently. Student saturation due to less monotonous and less exciting learning. Viewed from table five it is known that the control class only experienced a slight increase because the printed book in the learning process is challenging to be understood by the students. Moreover, print books do not contain detailed steps in learning. In addition, the printed book as a reference is rarely published and has a higher price. Conventional knowledge makes students saturated, so many students become less concentrated in receiving the subject matter [10][11].

However, seen from the table ten where learning using e-book based on digital sea learning has increased. This explains that eBooks are more effectively used in learning than in printed books. The use of sea-based digital learning has some advantages:

a. Accelerate the pace of learning and help teachers to make better use of time.

b. Reduce the burden of teachers in presenting information, so it can be more fostering and developing the passion.

c. Reduce the control of rigid and traditional teachers.

d. Provide opportunities for students to develop in accordance with its ability.

e. Provide a more scientific basis for learning.

f. Better consolidate learning by improving the ability of learning resources.

g. Allows to learn in real time and at any time

h. Provide direct knowledge.

i. Allows broader learning presentation, by presenting information capable of breaking geographic boundaries.

The effectiveness of sea-based online learning eBooks in line with research that says that there is an influence of internet utilization on student achievement [11][10][12]. Learning with interactive multimedia is more effective than learning without resorting to interactive multimedia [13][14]. Therefore the application of this learning media combines digital book (software) followed by the delivery of messages with digital sea learning that students receive using computers, laptops and even smartphones (hardware).

\section{Conclusion}

The results of research and discussion have been elaborated; it can be concluded that based on digital sea learning ebook effectively used in learning cookies and candies. This is shown by the submission of the accepted hypothesis. The calculation can be seen from $t$ arithmetic greater than $t$ table. Based on research 
findings that have been done e-book based on sea digital learning can be used in other knowledge especially vocational material. In addition, sea-based learning eBook can be used for distance learning. Advanced research is needed to find out the usefulness of eBooks in reducing student addiction to social media. It is necessary to have a policy in Higher Education to use eBooks as an interactive way of learning.

\section{Acknowledgments.}

This research is funded by Beginner Lecturer Research from Research and Development Agencies and Community Service, Universitas Sarjanawiyata Tamansiswa, Yogyakarta, Indonesia.

\section{References}

[1] D. Muste, "The Role of Communication Skills in Teaching Process," 2016.

[2] L. Outcome, "Empirical CALL evaluation: The Relationship Between Learning Process and Learning Outcome," CALICO J., vol. 26, no. 1, pp. 108-122, 2008.

[3] BPP Learning Media, "ACCA P3 - Business Analysis," ACCA P3 - Bus. Anal. Study Text 2016, no. September 2016, pp. 23-63, 2015.

[4] F. T. Leow and M. Neo, "Interactive multimedia learning: Innovating classroom education in a Malaysian university," Turkish Online J. Educ. Technol., vol. 13, no. 2, pp. 99-110, 2014.

[5] Association of Internet Service Providers Indonesia, "Penetration and Behavior of Indonesian Internet Users 2017," Asos. Penyelenggara Jasa Internet Indonesia., pp. 1-39, 2017.

[6] R. Twum, "Utilization of Smartphones in Science Teaching and Learning in Selected Universities in Ghana," J. Educ. Pract., vol. 8, no. 7, pp. 216-228, 2017.

[7] N. K. M. Wulandari, I. G. M. Darmawiguna, D. S. Wahyuni, J. Pendidikan, T. Informatika, and U. P. Ganesha, "Survey Deskriptif Optimalisasi Kalangan Mahasiswa Dan Siswa Se-Kota Singaraja," vol. 3, no. November, pp. 401-410, 2014.

[8] A. S. Sari, "The Development of Digital Book through Sigil Application in Cookies and Candys Lessons," Sci. Tech, vol. 1, no. 2, pp. 46-54, 2016.

[9] M. J. Ferreira, F. Moreira, C. S. Pereira, and N. Durão, "The Role of Mobile Technologies in the Teaching / Learning Process Improvement in Portugal," 8th Annu. Int. Conf. Educ. Res. Innov. (ICERI 2015), no. 16th-18th November 2015, pp. 4600-4610, 2015.

[10] Y. W. Li, "Transforming Conventional Teaching Classroom to Learner-Centred Teaching Classroom Using Multimedia-Mediated Learning Module," Int. J. Inf. Educ. Technol., vol. 6, no. 2, pp. 105-112, 2016.

[11] J. H. Wittebols, "Empowering Students To Make Sense of an Information-Saturade World: The evaluation of information Searching and Analysis," Commun. Inf. Lit., vol. 32, no. 4, pp. 779-809, 2008.

[12] E. Soloway, C. Norris, and A. Hossain, "Using Smartphones as Essential Tools for Learning," Educ. Technol., no. June, pp. 18-25, 2011.

[13] S. Cairncross and M. Mannion, "Interactive multimedia and learning: Realizing the benefits," Innov. Educ. Teach. Int., vol. 38, no. 2, pp. 156-164, 2001.

[14] M. Warschauer, "The paradoxical future of digital learning," in Learning Inquiry, 2007, vol. 1, no. 1, pp. 41-49. 